\author{
Sylwia Kaczmarek \\ ORCID 0000-0001-7737-4455 \\ University of Lodz \\ Institute of Geography of the City and Tourism \\ sylwia.kaczmarek@geo.uni.lodz.pl
}

\title{
RUINISATION AND REGENERATION IN THE TOURISM SPACE OF HAVANA
}

\begin{abstract}
The author's aim is to conduct an ethical analysis of degradation and regeneration processes in tourism space, using the example of Havana, Cuba. This is in the context of social relations between tourists and local inhabitants, as well as assessing the significance of regular patterns in these processes and their impact. As a result of the analysis, the author identified the causes of the ruinisation of tourism space in Havana, the exogenous and endogenous factors which influence this process, two types of regeneration undertaken as remedial action, as well as establishing the relationships between local inhabitants and tourists. The research results are followed by commentary indicating those elements of social relations which should be taken into consideration when starting a process of the urban regeneration of tourism space, in order to relieve present and potential conflicts between the inhabitants and tourists.
\end{abstract}

Keywords: regeneration, tourism space, ruinisation, social relations, Havana.

\section{INTRODUCTION}

Global tourism space is shaped through a variety of activities whose aim is to satisfy the different and changing needs of tourism participants. Ways of developing valuable parts of the geographical environment include offering the users varied and changing forms of spending leisure time. A major feature of tourism space is its gradual, evolutionary development. The issue of the tourism area life cycle has been the subject of numerous studies, conducted all over the world since the 1980s (Butler 1980, 2006; AGARWAL \& SHAW 2007; BONIFACE \& COOPER 2001; COOPER 2005; DEWAILly 1996; DeWAILLY \& PlameNT 2000; SMith \& RichaRdS 2012; JOHNSTONE 2001, etc.). They usually point to the progressive character of the changes (the new way of using space is a more complex, superior form of space organization than the previous ones). An analysis of the life cycle of individual tourist destinations and regions confirms that with time they lose popularity, elements of tourism infrastructure become old and degraded, and the attraction of some assets weakens or even disappears (e.g. due to degradation) which results in a decreasing number of tourists and negative economic consequences. Changes in human needs and, consequently, patterns of individual and collective behaviour during tourist stays requires not only making continuous adjustments in the area (modernization), but also modifying ideas on how tourism space can be used. The coincidence of these two processes, the ageing of the infrastructure and changes in tourists' preferences, leads to a situation when the number of people visiting an area starts to decrease dramatically.

The shaping of tourism space depends on many factors which can be divided into two groups: exogenous (coming from outside the region) and endogenous (generated locally). The first group includes geopolitical, administrative, legal, economic, cultural and environmental conditions, while the second, the topographic features of the area, the socio-spatial structure of the local population, their knowledge and skills, local authorities' mode of management, the type and quality of the existing assets and development, as well as transport accessibility. Tourism space transformations caused by both groups of factors may contribute to its development, but they may also cause stagnation, crisis, degradation and, as a result, eliminate tourism from the area. There are different forms of tourism space 
(WŁODARCZYK 2009) occurring in both rural (not urbanized) and urbanized areas.

Tourism space in a city is always a part of the urban space of exchange (KACZMAREK 2012). It connects the inhabitants and its other users, including tourists, and puts them in various types of relationship. Tourism, which is commonly present in contemporary cities, is an integral element of the space of exchange, and in this way undergoes changes in the way infrastructure elements are used and organized. The exogenous and endogenous factors for using tourism space often lead to the degradation of whole areas, an economic crisis, the ruinisation of the existing infrastructure and, subsequently, a need for difficult investment decisions, including regeneration. Moreover, these factors shaping urban tourism space have an influence on local social relations (KACZMAREK 2015). Thus, the following research question may be posed: how do remedial transformations of the degraded urban tourism space, and especially its regeneration, influence the social relations between inhabitants and tourists?

\section{DEGRADATION, RUINISATION AND REGENERATION IN TOURISM SPACE}

Degradation of tourism space will be understood here as a spontaneous, unplanned, uncontrollable process of decreasing the value (wearing down) of the physical fabric, as well as disturbing or damaging the stable, positive relations between investors, tourists and local communities (KACZMAREK 2017, KACZMAREK \& KOWALCZYK 2016). The degradation of urban tourism space is caused by the changing needs of its users and modifications to its development, as well as the political, social and economic changes which are taking place in near and more distant environments. The harmful processes caused by tourism and observed locally are a particular form of social degradation in tourism space. They appear mostly due to the discrepancy between the expectations of tourism investors (especially huge hotel chains, air carriers, etc.) and the local wishes. The former looks at an area as a segment of space where they invest in accordance with current expectations and hope to draw profits proportional to expenditure. The latter usually do not participate in such planning, have a limited influence on the way tourism infrastructure functions, and very rarely participate in the benefits, instead, they directly experience losses. Thus, they feel ignored and abused, which in the long run may cause frustration, or even aggression, towards tourists. From this point of view, degradation involves damage to friendly socio-cultural and economic relations, based on mutual benefits, which should be developed in tourism space between the inhabitants and tourists.
A consequence of tourism space degradation is ruinisation, i.e. the ruining of the existing structure which occurs in material (physical), economic and sociocultural spheres (KACZMAREK 2017). Although degradation and the subsequent ruinisation of tourism space have been elements throughout history, with the appearance of mass tourism in the $20^{\text {th }}$ century and its present continuous and dynamic development, they have gained a new dimension and significance. The origins of degradation in various parts of tourism space vary; the course it takes, its intensity and outcomes, including ruinisation also vary. Generally, the causes of degradation in tourism space can be divided into several categories, originating from exogenous and endogenous factors:

- the ageing of infrastructure and lack its of adjustment to the continuous and fast-changing needs of the users (including the lack of appropriate care for maintenance and management);

- reduced assets due to their inappropriate use, excessive exploitation or even intentional ruinisation;

- a change in the expectations of tourism participants as regards models of recreation and the ways of spending leisure time;

- the inadequacy of tourism services in relation to tourists' expectations;

- a change in the users' social profiles (elimination of certain social groups or a decrease in their significance, the appearance of new ones, until now absent from the market);

- strong competition between areas, especially when new locations offering similar features of the natural environment have a more modern infrastructure giving a more varied stay; in addition, they are easier to reach by transport from areas of tourism demand;

- wrong decisions taken at different levels (local, regional or national), regarding the spatial economy and tourism space planning;

- the political situation in neighbouring countries, the lack of a sense of security among the tourists (military conflicts, threat of terrorist attacks, social conflicts, an unstable economic and political situation) due to various local and global reasons;

- natural threats (the probability of extreme weather conditions: hurricanes, floods, earthquakes, volcanic eruptions, etc., also the presence of dangerous animals or plants);

- the quality of the local natural environment (threat of ecological disaster);

- other threats and incidental factors which are difficult to predict (the occurrence of dangerous diseases which are hard to treat, food poisonings, forest fires, etc.); 
- a negative (real or stereotypical) image of the area in the area of tourist demand (Kaczmarek 2015).

The significance of the factors identified at individual locations (cities, regions) varies, therefore each case of degradation in tourism space is a combination of particular conditions and circumstances, so it should be analysed separately. Coincidences in ways of organizing and using areas, the political and cultural contexts and the geographical location of tourism space are the basis for indicating certain similarities in their past which have already caused or contributed largely to the degradation. It seems, however, that the identification of similar causes cannot be generalized as regards decisions concerning the choice of the remedial action to decrease its negative impact. The ruinisation of tourism space as a consequence of degradation is a process which is being increasingly identified in various places all over the world.

Even though every kind of degradation is harmful for the area where it occurs, the correct identification of its causes is very important for the process of mitigating the negative effects, i.e. by implementing a variety of remedial scenarios. The most common activities involve the modernization and diversification of tourist infrastructure, extending the offer of recreation available at a given location, creating a new image for the area, highlighting new assets, and making tourists interested and potentially willing to visit. These are activities focused above all on improving those aspects which form the tourist product of the degraded area, do not always bring good results and can complicate the existing situation even further (BOUJROUF \& TEBBAA 2011; HARRISON 2001; JOHNSON \& LEWIS 2007; WEAVER 2012; SMITH \& RICHARDS 2012; KACZMAREK 2006; SCHEYEVENS 2002; JOHNSTON 2001).

In this respect, implementing the process of regeneration appears to be a remedy for degraded areas in tourism space, where the process of ruinisation has occurred. Regeneration is understood here as a sequence of planned actions, whose purpose is to revive a degraded area economically and change its spatial and functional structure, thus leading to economic and social stability. Every regeneration has its spatial, social, economic and cultural aspects (KACZMAREK 2001, 2015). A significant element of planning the regeneration of tourist areas is the issue of the decision-makers, i.e. the individuals and institutions who decide what action should be taken. Depending on the location of tourism space, there are different relations between the owners of tourist facilities (including all components of the tourist infrastructure) and their users (tourists), the local administrative authorities (state and local government), and the inhabitants. In some places, the interests of all the users in this particular "game for space" do not necessarily coincide and may generate conflict.

\section{RESEARCH METHODOLOGY}

In order to address the research problem, an analysis of the social relations which result from the process of regenerating degraded and ruined urban tourism space, the author chose the case study method. According to YIN (2014), it is an academic method which enables the researcher to analyse contemporary phenomena and processes with reference to present reality. This choice is based on the following criteria: the form of the research questions (what is the course of the process? Why does it occur in this way?); a focus on the present facts (here and now); and the lack of a requirement to verify them. There are three kinds of case study: descriptive (describing a process or phenomenon); explanatory (description and explanation of the causes of processes or phenomena); and exploratory (based on an analysis of the research questions, as well as the procedures which will be used in subsequent stages). If the studied phenomena or processes are widely spread, crucially important, unique, innovative or longlasting, only one case study may be carried out, as presented in this article. Conducting research with the use of the case study method in the context of tourism geography requires preparing theoretical assumptions (sometimes referred to as 'building the theory'), collecting a lot of data from a number of sources (socalled 'triangulation'), and undertaking field study (in situ) which helps to verify the data from other sources.

In the geographical case study analysis presented here, concerning the transformation of urban tourism space, its ruinisation and regeneration, and the ways in which it can be made use of, the author used a study procedure divided into five stages:

1) observation (the facts) in situ;

2) description and delimitation (identifying the qualities);

3) explanation (the relationships);

4) identifying the changes (the outcomes);

5) evaluation (the present state and its assessment).

The research was conducted in Havana, in two stages, in 2014 and 2015, and the capital of Cuba was chosen as a city illustrating the influence of the exogenous and endogenous factors on the shaping of tourism space, particularly the social relations it generates.

\section{HAVANA (CUBA) CASE STUDY}

The capital of Cuba, Havana, similar to the other parts of this Caribbean island, has been very popular with tourists since the 1920s. They mostly arrive from nearby USA and Canada. The main asset of the island is its 
climate, between tropical and subtropical, with a low annual temperature range (the highest average temperature is $28.7^{\circ} \mathrm{C}$ in August, the lowest $21^{\circ} \mathrm{C}$ in January), with considerable exposure to sunlight. In addition, it has lush vegetation, vast sandy beaches, and many examples of interesting architecture dating back to the times when the island was a Spanish colony. Between 1930 and 1950, the main tourist product of the capital was the entertainment industry, including (legal) gambling. Numerous casinos were opened by American investors involved in organized crime, luxury hotels were built, along with dance clubs and restaurants, while the offer included golf and horseriding clubs, as well as horse-racing events. That infrastructure enabled many Americans and Canadians to enjoy a relatively cheap holiday. An additional advantage was the sunny climate, picturesque seaside location and interesting architecture. US citizens visited Cuba, and especially Havana, during the prohibition era. At that time, a modern district, called Vedado, was built dedicated to tourists, with a large number of hotels, restaurants and entertainment establishments. The buildings that appeared alongside the tourist infrastructure included elegant villas and multistorey houses built in the Art Deco style, consisting of apartments for wealthy members of Cuban society at that time. The rapid development of the entertainment, recreational and gambling tourism was supported by the authorities, especially when Fulgencio Batista was chosen as president in 1933. He ruled as a dictator until 1958. At the same time, its social and economic diversity increased significantly. Apart from the welloff classes (bourgeoisie, entrepreneurs, some members of the intellectual elite and government representatives) who took advantage of the tourists' presence, there were other, much more numerous social groups of poor citizens (e.g. industrial and port workers, those working on sugar cane plantations). A division that had a significant influence on the mood in Cuban society critical of the regime (HENTHORNE 2018).

The first symptoms of the tourist function in Havana failing could be seen during World War II, which for obvious reasons considerably decreased the inflow of tourists, especially after the US joined the coalition of allies fighting fascism. Right after the war, the economic situation of Cuba became difficult due to changes on the political map of the world, new ideological differences (the growing position of the USSR), and the beginnings of the Cold War. In Cuba, the economic crisis increased the radicalization of social attitudes and fostered an active communist movement led by Che Guevara and Fidel Castro. In 1958, the Cuban Revolution broke out under the leadership of Fidel Castro who abolished the dictatorship of president Batista and introduced a communist system, nationalizing the economy (industry, agriculture, services) and expropriating American enterprises. The opponents of the new authorities left the island and a period of political isolation in the Caribbean region began. The new state policy, promoting the development of the communist social equality system stopped the inflow of tourists visiting Cuba, or even eliminated tourism, which led to the gradual degradation of the existing tourist infrastructure, identified with the previous, hated period. The stagnation of the tourist function, which involved preventing visits from well-off foreigners from North America, lasted until 1994, i.e. for over 35 years (HENTHORNE 2018). Over that time, a part of the existing tourist infrastructure was ruined due to a lack of proper care, buildings being used for other purposes, but mainly the scarcity of financial resources for conservation and necessary modernization. The process of slow but steady degradation of the material fabric affected other buildings erected before the revolution as well (housing, public utility buildings). As a result, Havana, particularly in its central part, became a neglected city, where dilapidated houses and even ruins and bearing traces of former grandeur are still a common sight today (Photo 1). These buildings include elements of the old tourist infrastructure, such as hotels (Photo 2). The city is inhabited by people who every day face a problem of constant shortages of basic goods and products (food, hygiene products, clothes, footwear, etc.). The overpopulated housing, whose condition is constantly deteriorating, and the lack of sanitary installations of an acceptable standard affect, the local population even more painfully. The inhabitants' living conditions still significantly deviate from European or American standards (Photos 3 and 4). Regrettably, this situation seems long-term and permanent.

A new phase in the functioning of the stagnating tourism space in Havana started in 1982, when the old town (Havana Vieja) was put on the UNESCO World Heritage List. Then, the authorities began to slowly change their attitude towards people visiting Cuba for

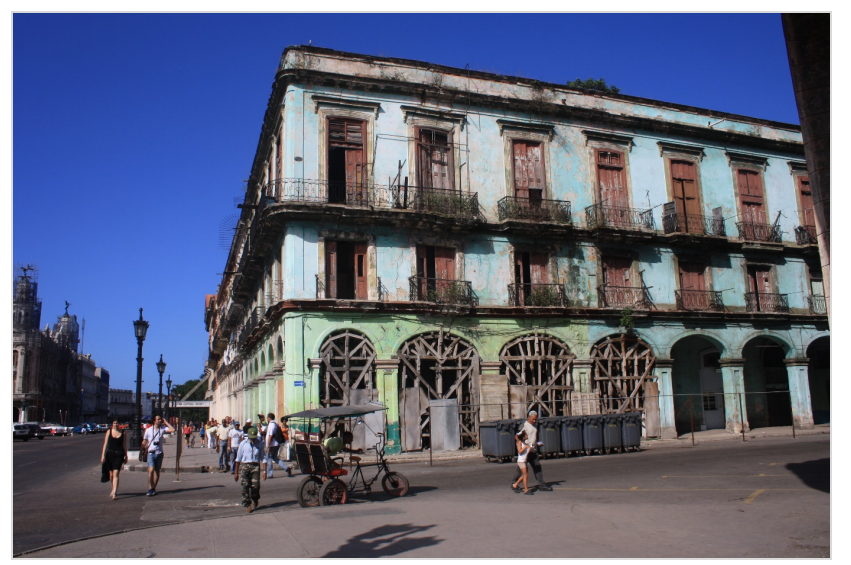

Photo 1. Havana - an example of degraded buildings in the city centre Source: KACZMAREK (2014) 


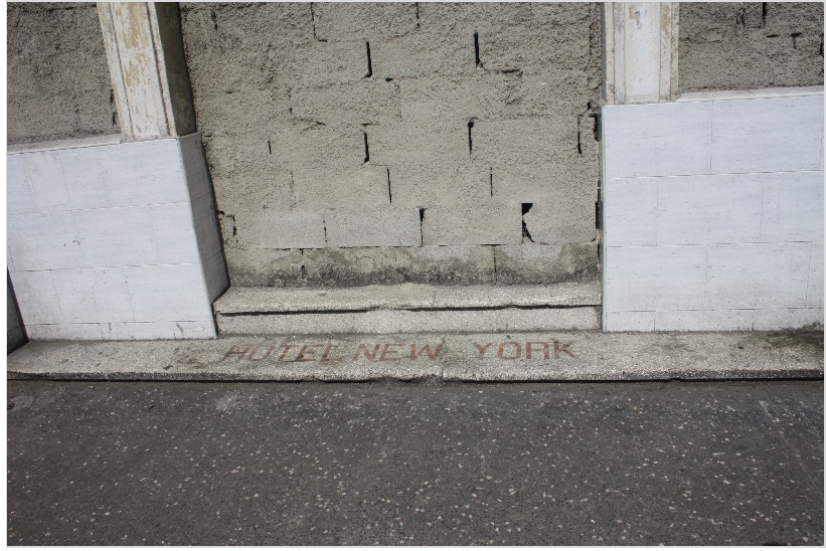

Photo 2. Havana - an example of the ruinisation of tourism space: the former New York Hotel Source: S. KACZMAREK (2014)
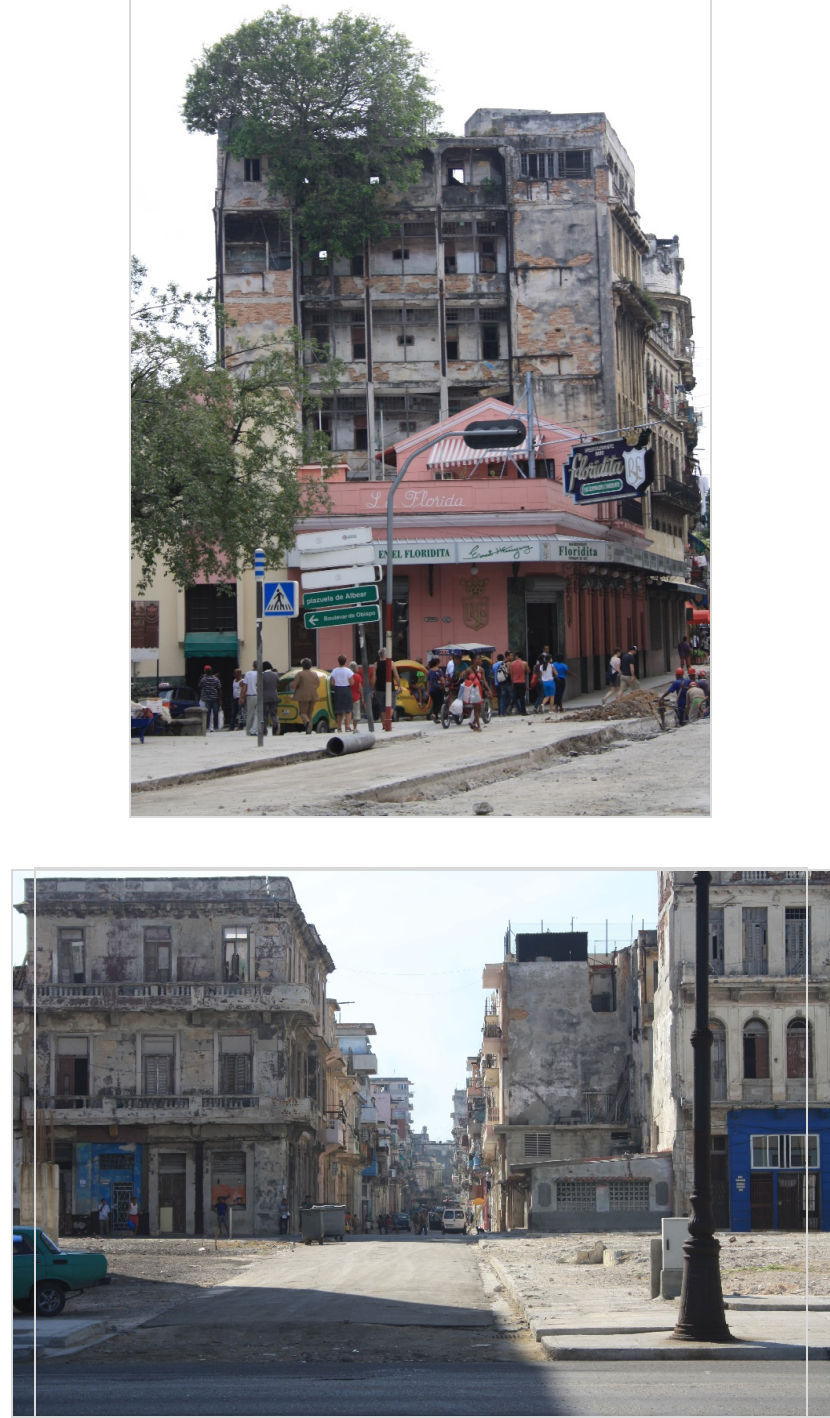

Photos 3 and 4. Examples of the degradation of the housing fabric in Havana

Source: S. KACZMAREK $(2014,2015)$ tourism and recreation. A new tourism policy was introduced step by step using tourism as a source of income to support the national budget. Political changes fostered the transformation and modernization of the capital. In the early 1990s, restoration work began in the city centre in order to restore the splendour of the old historical buildings, renovate and modernize the existing hotels, create museums and other elements of infrastructure (shops, art galleries, restaurants, cafes) which were significant components of tourism space (COLANTONIO \& POTTER 2006; KeRR 2009; VALLADARES 2018). The action taken at that time can be regarded as the first stage of regeneration (1997-2005) and included the central zone of the city giving new form to the existing historical fabric; its functional and spatial programme was mainly directed towards tourists (KERR 2009; PENARANDA \& CURRIE 2012; STAMM 2014). Renovated and modernized buildings were prepared so that they could be used by the constantly growing number of tourists; these accommodated museums, luxurious shops, art galleries, hotels and guest houses, restaurants and other establishments. It was a direct consequence of the Cuban authorities' decision to reopen the country to foreign tourism, being treated at the time as a stable source of money supporting the national budget. The activities (financed from the state budget and foreign resources) resulted in a zone in the city centre which is nearly completely devoid of residents (they have been relocated to other parts of the city) and whose users are tourists (REYNOLDS \& WOLFE 2000) (Photos 5 and 6).

The new tourism space became an enclave for tourists, who nevertheless often crossed its borders. Tourists wanted to penetrate the degraded quarters surrounding the centre perceived as an original feature of its fabric. Degraded Havana is also an example of a city repeatedly preserved in widespread perceptions through nostalgic feature films and documentaries, such as Wim Wenders' "Buena Vista Social Club", made in 1999, which tells the story of world-famous Havana musicians, urban folklore and the traditional culture of pre-revolution times.

The context of the features of tourism space in contemporary Havana has caused significant ethical misgivings concerning the relationship between tourists and inhabitants. Is it moral to treat a degraded city and the very poor living conditions of its inhabitants as tourist attractions? Is looking at poverty as a tourist attraction legitimate? Does the position of a tourist, who will leave the city in two or three days and return to their comfortable reality, not stir such misgivings? What is the social dimension of the regeneration process?

Providing answers to these questions requires looking into the relationship between tourists and inhabitants. As a part of urban space of exchange, tourism space is where various simultaneous flows meet as well as where modes of using and exploiting this space overlap. 
There are permanent or long-term users (the inhabitants) and a much more numerous group of incidental users (tourists coming from different parts of the world and from different cultures), for whom the stay in the city and use of its resources is temporary. In the inhabitants' eyes, these users of the infrastructure behave in a similar way even though the actual participants are new each day. Thus, the mutual relations between the two groups, which should be based on harmony, mutual tolerance and respect, become particularly important in the context of programming and implementing remedial processes in the degraded urban space. Otherwise, there is a risk of conflict between them because there are still clear differences in their standards of living. The latter mostly stay in luxury enclaves, such as hotels or holiday resorts, and they do not participate in the difficult reality or face problems of an insufficient supply of basic products and services.

An attempt to solve this conflict of interests is a new approach to the relationship between Havana's inhab- itants and tourists, which can be found in the 'formula' used in the $2^{\text {nd }}$ phase of regenerating the central zone of the city. The project has been implemented in stages since 2008 and encompasses areas situated along the waterfront of the old port in Havana. The old, warehouses and other former-industrial buildings standing along the railway line are successively being transformed into gastronomic establishments and shops. However, this offer is being directed towards city inhabitants and tourists alike, which can be seen in the new programme for the use of space and the active local involvement in its implementation. The new approach is also demonstrated by the way in which the urban public space is arranged in this zone. The new phase of regeneration very strongly accentuates the historical heritage of a former-industrial area as a fragment of the city and its inhabitants' history (Photos 7 and 8).

Transformed buildings feature many information boards, documenting the past of these buildings with photographs and references to the people who once
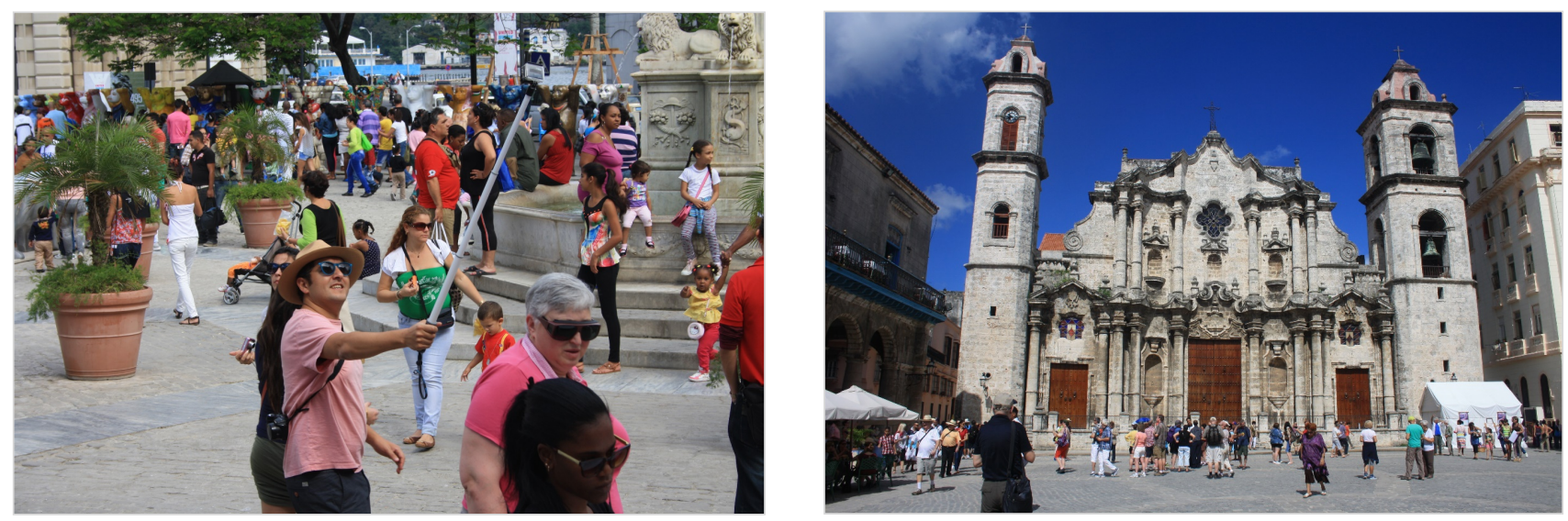

Photos 5 and 6. Tourist areas in the centre of Havana

- the effect of the first phase of regeneration

Source: S. KACZMAREK $(2014,2015)$
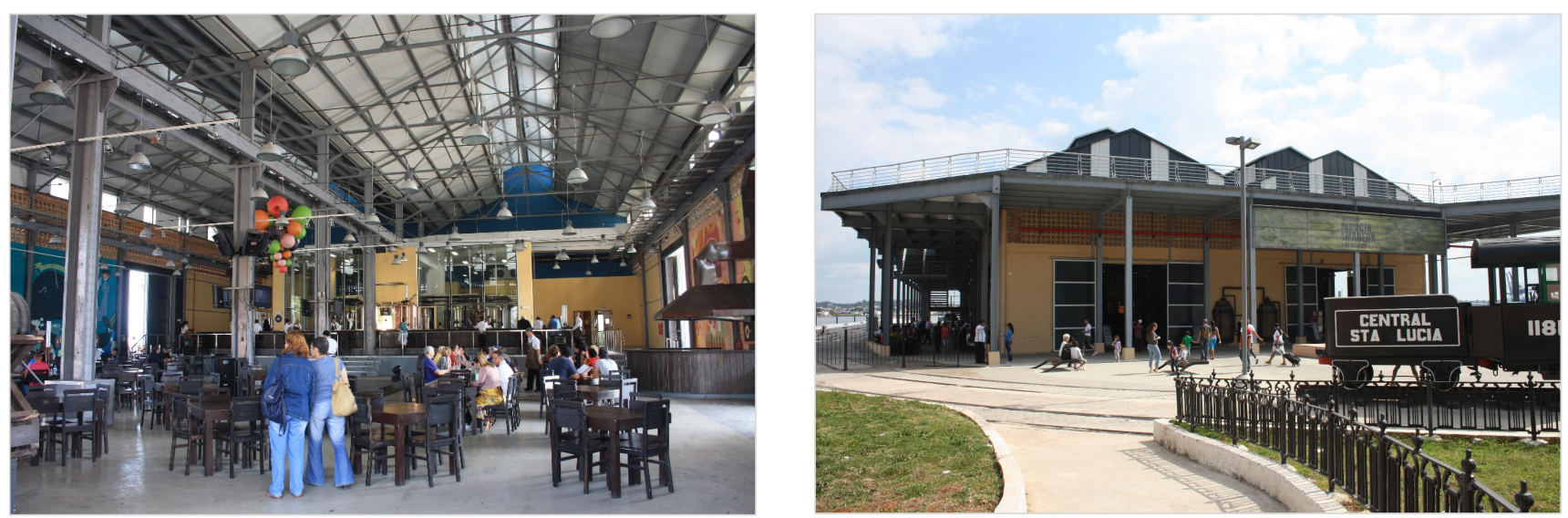

Photos 7 and 8. Public and tourism space in Havana, in the waterfront zone - the effect of the second phase of regeneration Source: S. KACZMAREK (2015) 
lived and worked there. The educational value of this means of exposing the past is undeniable because it serves both tourists and inhabitants alike, particularly appreciating the latter as the driving force of the city's development.

\section{SUMMARY}

Regeneration in Havana, conducted to a new formula, is addressed to inhabitants as well as tourists. It makes it possible to maintain a balanced partnership between the two groups, both present in the urban space of exchange (which is at the same time a tourism space). In this way, it gradually eliminates the division according to which the tourists were the 'better - richer' users of the city, and the inhabitants were the 'worse-poorer' users. The city is primarily a living environment for its inhabitants and that is why modernization activities, including regeneration, should above all lead to the gradual improvement of their living conditions. Tourists as episodic users of the urban space of exchange, which they turn into a tourism space, should understand their visitor status. A separate and difficult issue is the tourists' attitude to the visited area, as they still treat the inhabitants in a patronizing way, do not understand the hardships of their everyday life, treat the degraded city as original, unique 'scenery', which is an attraction for tourists coming from areas where cities are in a much better condition.

A harmonious coexistence of local people and tourists in the materially degraded city of Havana requires a reasonable and rational exploitation of tourism space. But most of all, it is necessary to treat the inhabitants as subjects, identify their needs and expectations, as well as relate them to the usually different expectations and needs of tourists. The process of regenerating Havana should then follow the integration model (KACZMAREK 2001), which, on the one hand, makes it possible to preserve its unique features and present it to tourists, and on the other, it will provide proper living standards and allow the inhabitants to live with dignity.

\section{BIBLIOGRAPHY}

AGARWAL S., SHAw G. (eds.), 2007, Managing costal tourism resorts: A global perspective, Channel View Publications, [s. 1.].

BONIfACE B.G., COOPER CH., 2001, Worldwide destinations: The geography of travel and tourism, Elsevier, [s. 1.].
Boujrouf S., TebBaA Q. (eds.), 2011, Tourisme et pauvreté, Editions des Archives Contemporaines, Paris.

BUTLER R., 1980, The concept of a tourist area cycle of evolution: Implications for management of resources, The $\mathrm{Ca}$ nadian Geographer, 24, 1, pp. 5-12.

BUTLER R.W. (ed.), 2006a, The tourism area life cycle, vol. 1: Applications and modifications, Channel Viev Publications, Clevedon-Buffalo-Toronto.

BUTLER R.W. (ed.), 2006b, Tourism area life cycle, vol. 2: Conceptual and theoretical issues, Channel Viev Publications, [s. 1.].

COlANTONIO A., POTter R.B., 2006, Urban tourism and development of the socialist state: Havana during the "special peri$o d^{\prime \prime}$, Ashgate, [s. 1.].

COOPER CH. et al., 2005, Tourism: Principles and practice, Pearson Education, [s. 1.].

DeWAILLY J.M., 1996, L'espace touristique: du réel au virtuel, 28é Congrés sur la Géographie, Haga.

Dewailly J.M., Plament E., 2000, Le tourisme, Campus Géographie, SEDES, [s. 1.].

HARRISON D., 2001, Tourism and the less developed world: Issues and case studies, Cabi Publishing, [s. 1.].

Henthorne T.L., 2018, Tourism in Cuba. Casinos, castros and challenges, Emerald Publishing Ltd., [s. 1.].

JoHNSON D.L., LEWIS L.A., 2007, Land degradation: Creation and destruction, Rowman \& Littlefield Publishers, LanhamBoulder-New York-Toronto-Oxford.

JOHNSTON C.S., 2001, Shoring the foundations of the destination life cycle model. Part 1: Ontological and epistemological considerations, Tourism Geographies, 3, 1, pp. 2-28.

KACZMAREK S., 2001, Rewitalizacja terenów poprzemystowych. Nowy wymiar w rozwoju miast, Wydawnictwo Uniwersytetu Łódzkiego, Łódź.

KACZMAREK S., 2006, Urban tourism - the blessing or the curse, [in:] R.C. Lois Gonzáles (ed.), Urban changes in different scales: systems and structures, Universidade de Santiago de Compostela, [s. 1.], pp. 361-368.

KACZMAREK S., 2012, Kultura gospodarowania przestrzenią w mieście, Studia Miejskie, 5, pp. 9-19.

KACZMAREK S., 2015, Degradacja i rewitalizacja przestrzeni turystycznej. Refleksja teoretyczna, [in:] M. Durydiwka, K. Duda-Gromada (eds.), Przestrzeń w turystyce. Znaczenie i wykorzystanie, Wydział Geografii i Studiów Regionalnych UW, Warszawa, pp. 27-37.

KACZMAREK S., 2017, Demolowanie jako radykalne narzędzie w procesie rewitalizacji, Studia Miejskie, 28, pp. 9-20.

KACZMAREK S., KOWALCZYK A., 2016, Rewitalizacja terenów poprzemysłowych i turystycznych, Folia Turistica, 41, pp. 283-309.

KERR R., 2009, The metamorphosis of Cuban architecture; development, decay and opportunity, University of Edinburgh, Edinburgh.

PeÑaranda Currie L., 2012, From colonial port to postrevolution: Urban planning for 21st century Havana, consilience, The Journal of Sustainable Development, 8, pp. 50-69. 
REYNOLDS WOLFE L., 2000, Contesting the global restoration and neighborhood identity in Old Havana, http:/ /lasa.interna tional.pitt.edu/Lasa2000/ReynoldsWolfe.PDF; 21.07.2018.

Ryan CH., 2003, Recreational tourism: Demands and impacts, Channel View Publications, Clevedon-Buffalo-TorontoSydney.

SCHEYVENS R., 2002, Tourism for development: Empowering communities, Pearson Education, [s. 1.].

SMITH M., RichaRDS G., 2012, Routledge handbook of cultural tourism, Routledge, [s. 1.].

StAmM L., 2014, Deconstructing the dual city: pPreservation and tourism in La Habana Vieja, Senior Capstone Projects, Paper 385, Vassar College, Digital Window @ Vassar.
VALlADARES A., 2018, The built environment in contemporary Old Havana: Building systems in a historic district, School of Urban Planning, McGill University, Montreal.

WEAVER D., 2012, Sustainable tourism theory and practice, Routledge, [s. 1.].

WŁodArczYK B., 2009, Przestrzeń turystyczna. Istota, koncepcje, determinanty rozwoju, Wydawnictwo Uniwersytetu Łódzkiego, Łódź.

YIN R.K., 2014, Studium przypadku w badaniach naukowych. Projektowanie $i$ metody, Wydawnictwo Uniwersytetu Jagiellońskiego, Kraków.

Article received: 17 October 2018 r. Accepted:

29 November 2018 r. 